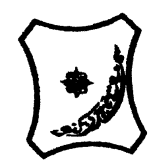

Bayero Journal of Pure and Applied Sciences, 13(2): 79 - 83

Received: April, 2020

Accepted: August, 2020

ISSN $2006-6996$

\title{
INFLUENCE OF HAEMATOLOGICAL PROFILE ON THE EXERCISE CAPACITY OF CHILDREN WITH SICKLE CELL DISEASE IN KANO
}

\author{
Adeyinka, O., ${ }^{1}$ Badaru, U.M., ${ }^{2 *}$ Nuhu, J.M., ${ }^{2}$ Ahmad, R.Y., ${ }^{2}$ Bello, B., ${ }^{2}$ Nura, G. ${ }^{3}$ \\ and Bello, A.M. ${ }^{3}$ \\ ${ }^{1}$ Department of Physiotherapy, National Orthopaedic Hospital Dala, Kano, Nigeria \\ ${ }^{2}$ Department of Physiotherapy, Faculty of Allied Health Sciences, Bayero University, Kano, Nigeria \\ ${ }^{3}$ Department of Medical Laboratory Science, Faculty of Allied Health Sciences, Bayero University, \\ Kano, Nigeria \\ *Correspondence: Email: umbadaru.pth@buk.edu.ng OR badaruum@yahoo.com \\ Mobile: +2348035913759
}

\section{ABSTRACT}

The Exercise Capacity (ExC) of children with sickle cell disease (SCD) may be influenced negatively by both haematological and environmental factors. This study aimed to assessthe influence of haematological profile on the EXC of children with SCD in Kano and to ascertain the safety of conducting 6 minute walk test (6MWT) on those children.In the cross-sectional survey, 162 children were recruited from Murtala Mohammed Specialist Hospital, Kano. Each of them walked to-and-fro for 6 minutes on a 10 meter marked level floor at their own walking pace in order to determine their actual 6 minute walk distance (6MWD). The actual 6MWD was compared with a predicted one in order to determine their EXC. Full blood count was used to evaluate haematological profiles. The data were analysed with Pearson product moment correlation and unpaired $t$ test, at a level of significance of $p<0.05$ using SPSS version 20 . Results showed that seventy (70) males (43.2\%) and ninety two (92) females (56.8\%) with mean age of $10.7 \pm 3.27$ years took part in the study. The actual 6MWD was $366.20 \mathrm{~m} \pm 59.88 \mathrm{~m}(95 \% \mathrm{CI}=356.91 \mathrm{~m}$ $375.49 \mathrm{~m}$ ) which was $59.17 \%$ of the predicted one. ExCcorrelated with each of White blood cell count $(W B C)(r=-0.22 ; p=0.005)$, Sex $(r=-0.27 ; p=0.001)$ and age $(r=0.19 ;$ $p=0.013)$. None of the participants experienced exercise-induced vaso-occlusive crisis during or immediately after the 6MWT.It was concluded thatinfection (signified by increased WBC count) and female gender have negative influence on EXC.6MWT is safe to be performed by children with SCD.

Key words: Sickle Cell Disease, Haematological Profile, Exercise Capacity, Six Minute Walk Test

\section{INTRODUCTION}

Sickle Cell Disease (SCD) is an inherited hemoglobinopathy (Chirico et al., 2016; Martinet al., 2018) that affects millions of people worldwide (Tsaras et al., 2009). The disorder is most commonly found among the people living in the sub-Saharan Africa (Tsaras et al., 2009;Mitchell, 2018).It occurs when a hydrophobic valine replaces a hydrophilic glutamicacid (Mitchell, 2018) at the sixth position on the beta globin chain on chromosome 11 (Steinberg,2006) giving rise to abnormal hemoglobin ( $\mathrm{HbS}$ ) which is less soluble when deoxygenated (Mitchell, 2018). The increasing need for more oxygen supply to active muscles during strenuous (anaerobic) exercise may initiate metabolic changes that lead to $\mathrm{HbS}$ polymerization, sickling of red blood cell (RBC), vascular occlusion and endothelial damage (Tsaras et al., 2009; Waltz et al., 2012). In SCD, strenuous exercise decreases arterial oxygen concentration leading to acidosis, excess lactate formation and intravascular sickling (Connes et al., 2011).It has however been revealed that RBC stiffness is only possible with the combined effects of deoxygenation and low pH (Xuet al., 2016).Strenuous exercise also leads to dehydration, hyperthermia (Tsaras et al., 2009, Mitchell, 2018),rhabdomyolysis, splenic infarction (Thompson, 2013), hemolysis(Platt, 1982)and sudden death (Tsaras et al., 2009, Fajardo and Tchandja, 2015; Mitchell, 2018). 
BAJOPAS Volume 13 Number 2,December, 2020

Sudden death can stem from conducting strenuous exercise in high altitude (Mitchell, 2018),rhabdomyolysis, heat stroke, acute renal failure, intravascular coagulation (Tsaras et al., 2009, Mitchell, 2018), dehydration (Mitchell, 2018) and cardiac dysrhythmia (Tsaras et al., 2009; Fajardo and Tchandja, 2015).Due to the aforementioned severe complications that are associated with strenuous exercise in SCD, clinicians have rarely prescribed exercise to individuals with SCD.

On a positive note, studies have however found that engaging in regular moderate intensity exercise is beneficial rather than harmful in patients with SCD (Chirico et al., 2012; Waltz et al., 2012; Messonnier et al., 2012; Faes et al., 2014; Hedreville et al., 2014). Moderate intensity exercise was found to decrease oxidative stress (Chirico et al., 2012; Faes et al., 2014; Chirico et al., 2016,Martin et al., 2018) inflammation and endothelial damage (Faes et al., 2014) and improved nitric oxide bioavailability(Martin et al., 2018).Moderate intensity exercise did not alter autonomic nervous system activity negatively (Hedreville et al., 2014), and it decreased microcirculatory flow abnormalities (Waltz et al., 2012).Beneficial exercise to individuals with $\mathrm{SCD}$ has to be aerobic (Tsaras et al., 2009; Connes et al., 2011), symptom limited, with adequate hydration (Tsaras et al., 2009; Tripette et al., 2010; Conneset al., 2011) and not to be conducted under adverse weather conditions (Joneset al., 2005; Connes et al., 2011). The aim of this study was to assess the influence of hematological variables on the Exercise Capacity (ExC.) of children with SCD and to determine the safety of conducting 6 minute walk test (6MWT) with the view to help physiotherapist prescribe exercises that are safe to the patients with SCD in a city that could experience extreme of weather conditions.

\section{MATERIALS AND METHODS}

The study wasa cross-sectional descriptive survey in which 162 children and adolescents with SCD, seventy males (43.2\%) and ninety two females (56.8\%) took part in the study. They were recruited from the out-patient SCD clinic in Murtala Mohammed Specialist Hospital, Kano using purposive sampling technique. The study was approved by the Ethics Committee of Kano State Ministry of Health and the consent of participants, and that of their caregivers, as the case applied, was sought and obtained. The height and weight of participants were measured using standard procedures; oxygen saturation was assessed with finger pulse oximeter. Blood samples were collected for FBC using autoanalyser (Sysmex XP-300, Germany) (Akinbami et $a l, 2012)$. The safety of the 6MWT was determined based on the presence or absence of crises during or after the exercise test. Occurrence of crises was score ' 0 ' point and absence of crises was scored ' 1 ' point.

\section{Procedure for conducting 6MWT}

The test was performed in a well-ventilated gymnasium14-meter long between 9am and $1 \mathrm{pm}$ daily. Each participant was instructed to stand and keep walking at his/her own pace to the 10 meters line and then return to the 0 meter repeatedly for 6 minutes. The totaldistance covered during the 6MWT by each of the patientswas recorded asthe actual six minute walk distance (6MWD).

All precautions to guard against development of crises have been adhered to very strictly. The patients have being on routine medical care (and also on hydroxy-urea) and free of frequent vaso-occlusive crises at-least in the last 3 months. The exercise was totally aerobic and symptom limited (i.e. exercise being terminated when symptoms of muscle cramping, fatigue, and shortness of breath ensues) with adequate hydration before and after the exercise and the training was conducted in a well-ventilated and conducive environment.

\section{Determination of ExC}

Participants that covered longer distance during the 6MWT (or have higher value of 6MWD) were regarded as having better ExC. However, ExC could also be categorised as normal, moderately decreased or severely altered by comparing the actual 6MWD for each patient with a predicted 6MWD (Dedeken et al., 2014). The predicted 6MWD was obtained using the standard regression equation below:

Males Predicted 6MWD $=196.72+(39.81 \mathrm{x}$

Age $)-\left(1.36 \times\right.$ Age $\left.^{2}\right)+(132.28 \times$ Height $)$

Females Predicted 6MWD $=188.61+(51.50 \mathrm{x}$

Age $)-\left(1.86 \times \mathrm{Age}^{2}\right)+(86.10 \times$ Height $)$ (Geiger et al.,2007).

1. When the actual 6MWD was greater than $80 \%$ of the predicted 6MWD $=$ Normal ExC

2. When the actual 6MWD was between $60 \%$ - $80 \%$ of the predicted 6MWD =Moderately decreased ExC

3. When the actual 6MWD was less than $60 \%$ of the predicted $6 \mathrm{MWD}=$ Severely Altered ExC (Dedeken et al., 2014). 
BAJOPAS Volume 13 Number 2,December, 2020 Data Analysis

The data were summarised with descriptive statistics and analysed with inferential statistics of Pearson product moment correlation and unpaired $t$ test, at a level of significance of $p<0.05$ using SPSS version 20.It was not possible to conduct inferential statistics on the safety of 6MWT because none of the participants had any crises during the exercise.

\section{RESULTS}

The mean age and body mass index of the participants were of $10.7 \pm 3.27$ years and 13.44 $\pm 1.79 \mathrm{~kg} / \mathrm{m}^{2}$ respectively. The mean 6MWD covered by the participants was $366.20 \mathrm{~m} \pm$ $59.88 \mathrm{~m}$. The average value of their predicted 6MWD was $618.93 \mathrm{~m} \pm 48.09 \mathrm{~m}$. This implies that the study participants were able to exercise at $59.17 \%$ of their predicted ExC.Only 2 (1.2\%) had Normal Exc, $80(49.4 \%)$ had moderately altered Exc and $80(49.4 \%)$ severely altered Exc. With regards to the safety of conducting $6 \mathrm{MWT}$, none of the participants experienced any exercise- related clinical sign of vaso-occlusive crisis during and immediately after the exercise.

Significant correlations were observed between ExC and each of Sex $(r=-0.27 ; P=0.001)$ and age $(r=0.19 ; p=0.013)$ of participants. Further analysis of ExC based on sex using student t-test analysis revealed that female participants have significantly lower $\quad(P<0.05) \quad$ ExC (mean=352.17 $\pm 54.87 \mathrm{~m}$ ) than their male counterpart (mean=384.63 $\pm 61.57 \mathrm{~m})$.

\section{Correlation between haematological profile and ExCof participants}

Mean valuesof haematological variables were $95.01 \pm 4.43 \%$ for oxygen saturation $\left(\mathrm{SPO}_{2}\right)$ post exercise,16.16 $\pm 6.10 \times 10^{3} / \mu \mathrm{L}$ for white blood cell (WBC) countand $84.73 \pm 8.38 \mathrm{fL}$ for mean cell volume (MCV) as presented in Table 1. Furthermore, there was significant negative correlation between ExC and WBC count $(P<0.05)$.

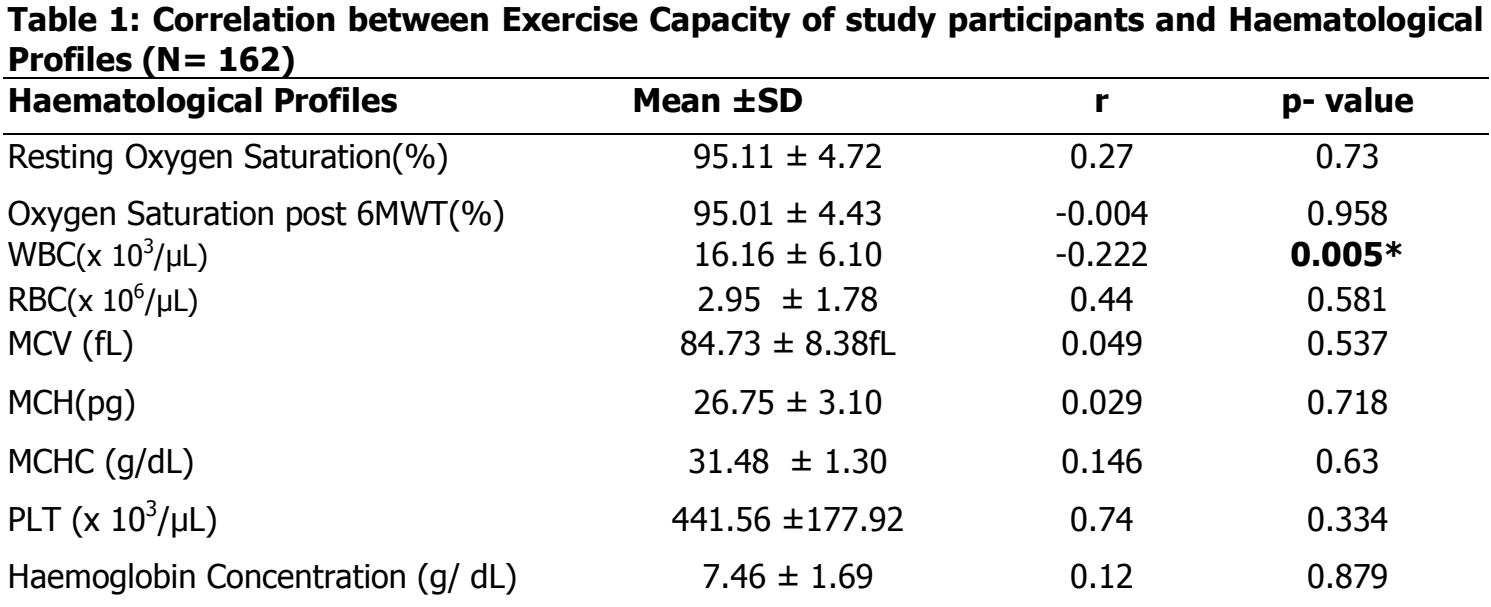

Key: *significant; $6 \mathrm{MWD}=$ six- minute walk distance; $\mathrm{WBC}=$ white blood cell count, $\mathrm{RBC}=$ red blood cell, $\mathrm{MCV}=$ mean cell volume, $\mathrm{MCH}=$ mean cell haemoglobin, $\mathrm{MCHC}=$ mean corpsularhaemoglobin concentration, $\mathrm{PLT}=$ platelet.

\section{DISCUSSION}

Despite the fact that Kano City is known for having adverse weather conditions at specific times of the year, the outcome of this study has revealed that low-moderate intensity aerobic exercise in the form of 6MWT is safe to be performed by individuals with SCD. This is because none of the participants in this study experienced any exercise induced clinical sign of vaso-occlusive crisis both during and immediately after the exercise. The implication of this finding is that the 6MWT can also be used as a form of endurance training for individuals with SCD provided that all the necessary precautions havebeen observed. A study has also observed that moderate exercise did not adversely affect the functioning of the autonomic nervous system in patients with SCD (Hedreville et al., 2014).

The ExC of the participants in this study is less than sixty percent of the predicted value, and this implies that most of them have severely reduced ExC levels. The finding on the deterioration of ExC in individuals with SCD is in line with the outcomes of other studies (Liem et al., 2009; Minniti et al., 2010; Hostyn et al., 2013; Waltz et al., 2013; Dedeken et al., 2014; Oharaet al., 2014). Previous studies have reported ExC values of $83.26 \%$ (Dedekenet al., 2014) and $74.56 \%$ (Waltz et al., 2013)of the predicted value which are higher than what was obtained in this study. 
BAJOPAS Volume 13 Number 2,December, 2020

This study found that there was significant negative relationship between infection which is represented by increased white blood cells (WBC) count and ExC. An increase in WBC count as observed in this study connotes presence of bacterial or fungal infection. This implies that increased infection episodes will lead to reduction in ExC among individuals with $S C D$. Individuals with $\mathrm{SCD}$ are prone to having functional asplenia and recurrent chest infection. This may lead to reduction in the exercise ability of the patient if not adequately treated. The outcome of this study on infection is in line with the finding of another studywhere significant relationship was found between increased WBC count (WBC) and ExC (Meloet al., 2017). Although the other selected haematological variables in this study all have no significant relationship with the ExC of the study participants at least individually, the observed reduction in ExCcould probably be associated with the combined influence of the reductions inthe concentrations ofseveralhaematological variables such as severe reductions in haemoglobin, pack cell volume, RBC and platelet in majority of the participants. The insignificant relationship between arterial oxygen saturation and ExC may probably be due to the fact that the average value of the arterial oxygen saturation of the study participant is within normal range both at rest and post exercise.

\section{REFERENCES}

Akinbami, A., Dosunmu, A., Adediran, A., Oshinaike, O., Adebola, P., and Arogundade, O. (2012): Haematological values in homozygous sickle cell disease in steady state and haemoglobin phenotypes AA controls in Lagos, Nigeria. BMC Research Notes. 5 (396):16.

Chirico, E.N., Martin, C., Faës, C., Féasson, L., Oyono-Enguéllé, S., Aufradet, E., Dubouchaud, H., Francina, A., CanetSoulas, E., Thiriet, P., Messonnier, L., and Pialoux, V. (2012): Exercise training blunts oxidative stressin sickle cell trait carriers. Journal of Applied Physiology.112: 1445-1453.

Chirico, E.N., Faës, C., Connes, P., Canet-Soulas, E., Martin, C., and Pialoux, V. (2016): Role of Exercise-Induced Oxidative Stress in Sickle Cell Trait and Disease. Sports Medicine. 46(5):629-39.

Connes, P., Machado, R., Hue, O., and Reid, H. (2011): Exercise limitation, exercise testing and exercise recommendations in sickle cell anemia. Clinical Hemorheology and Microcirculation. 49: 151-163.
Contrary to the findings in this study, low haemoglobin level had previously been linked with the ExC of individuals with SCD (Settyet al., 2003).Furthermore, significant correlation was also found between RBC deformability and ExCwhere it was revealed that it is not the total number of RBC that actually counts but the total number of viable ones (un-deformed RBC cells) (Liemet al., 2009). Also, previous studies have found significant correlation between pack cell volume and ExC (Liemet al., 2009; Waltz et al., 2013). In addition, a studyfound a significant relationship between oxygen saturation and ExC (Hostynet al., 2013).

Finally, this study found significant relationship between age and ExC. The positive correlation implies that the older the child the better the ExC.Furthermore, this study found that male participants have significantly better ExC than females. It is also possible that based on the positive correlation between age and ExC, males with higher mean age may have better ExC.

It was concluded that low-moderate intensity aerobic exercise in the form of 6MWT is safe to be performed by individuals with SCD and thatinfection signified by increased WBC count, gender and age have significant influence on the ExC of children and adolescents with SCD in Kano.

Dedeken, L., Chapusette, R., Le, P., Heijmanns, C., Devalck, C., Huybrechts, S., Ziereisen, F., Hanssens, L., Rozen, L., Noubouossie, D., Mujinga, M.N., Ferster, A. (2014): Reduction of the Six- minute Walk Distance in children with Sickle Cell Disease Is Correlated with Silent Infarct: Results from a Cross- Sectional Evaluation in a single centre in Belgium. PLOS ONE. 9: 1-5.

Faes, C., Balayssac-Siransy, E., Connes, P., Hivert, L., Danho, C., Bogui P. Martin, C., and Pialoux, V.(2014): Moderate endurance exercise in patients with sickle cell anaemia: effects on oxidative stress and endothelial activation. British Journal of Haematology. 164: 124-130

Fajardo, K.A., and Tchandja, J. (2015): ExerciseInduced Cardiac Arrest in a Sickle Cell Trait-Positive Air Force Recruit: A Case Report. Military Medicine. 180(3): e3724.

Geiger, R., Strasak, A., Treml, B., Gasser, K., Kleinsasser, A., Fischer V, Geiger, $H_{\text {., }}$ Loeckinge, A., and Stein, J.I.(2007): SixMinute Walk Test in Children and 
BAJOPAS Volume 13 Number 2,December, 2020 Adolescents. The Journal of Pediatrics. 150(4): 395-9

Hedreville, M., Charlot, K., Waltz, X., Sinnapah, S., Lemonne, N., Etienne-Julan M, Soter, V., Hue, O., Hardy-Dessources, M.D., Barthélémy, J.C., and Connes, P.(2014): Acute Moderate Exercise Does Not Further Alter the Autonomic Nervous System Activity in Patients with Sickle Cell Anemia. PLOS ONE. 9(4): e95563.

Hostyn, S.V., de Carvalho, W.B., Johnston, C., and Braga, J.A. (2013): Evaluation of functional capacity for exercise in children and adolescents with sickle-cell disease through the six-minute walk test. Jornal de Pediatria. 89(6):588-94.

Jones, S., Duncan, E.R., Thomas, N., Walters, J., Dick, M.C., and Height, S.E., et al. (2005): Windy weather and low humidity are associated with an increased number of hospital admissions for acute pain and sickle cell disease in an urban environment with a maritime temperate climate. British Journal of Haematology. 131: 530-533

Liem, R.I., Nevin, M.A., Prestridge, A., Young, L.T., and Thompson, A.A. (2009): Functional capacity in children and young adults with sickle cell diseases undergoing evaluation for cardiopulmonary disease. American Journal of Haematology.84:645 - 649.

Martin, C., Pialoux, V., Faes, C., Charrin, E., Skinner, S., and Connes P. (2018): Does physical activity increase or decrease the risk of sickle cell disease complications? British Journal of Sports Medicine. 52(4):214-218.

Melo, H.N., Stoots, S.J., Pool, M.A., Cavalho, V.O., Almeida, L.O.C.,Aragao, M.L.D., Agyemang, C., and Cipolotti, R.(2017): Physical Activity Level and Performance in the six- minute walk test of children and adolescents with Sickle cell disease. RevistaBrasileiradeHematologia Hemoterapia. 39 (2): 133-139.

Messonnier, L., Samb, A., Tripette, J., Gogh, B.D., Loko, G.,Sall N.D., Féasson, L., Hue, O., Lamothe, S., Bogui, P., and Connes, P.(2012): Moderate endurance exercise is not a risk for rhabdomyolysis or renal failure in sickle cell trait carriers. Clinical Hemorheology and Microcirculation. 51(3):193-202.

Minniti, C., Alam, S., Kato, G.J., Nouraie, M., Sable, C.,Ensing, G., Campbell, A., Rana, S., Darbari, D., Gladwin, M., Castro, O., and Gordeuk, V.R.(2010): Evaluation of Exercise Capacity In Children with Sickle cell disease by Six Minute Walk Test. Blood. 116:2664.

Mitchell, B.L. (2018): Sickle Cell Trait and Sudden Death. Sports Medicine - Open. 4 (19):1-6
Ohara, D.G., Ruas, G., Walsh, I.A.P., Castro, S.S., and Jamami, M. (2014): Lung function and six- minute walk test performance in individuals with sickle cell disease. Brazilian Journal of Physical Therapy.18(1): $79-87$.

Platt, O.S. (1982): Exercise-Induced Hemolysis in Sickle Cell Anemia: Shear Sensitivity and Erythrocyte Dehydration. Blood. 59 (5): 1055-60

Setty, B.N., Stuart, M.J., Dampier, C., Brolecki, D., and Allen JL. (2003): Hypoxemia in sickle cell disease: biomarker modulation and relevance to pathophysiology. Lancet. 362: $1450-1455$.

Steinberg, M.H. (2006): Pathophysiologically based drug treatment of sickle cell. Trends in Pharmacological Sciences. 27: 204-210.

Thompson, A.A.(2013): Sickle cell trait testing and athletic participation: a solution in search of a problem? Hematology.American Society of Hematology.Education Program:632-637

Tripette, J., Loko, G., Samb, A., Gogh, B.D., Sewade, E.,Seck, D., Hue, O., Romana, M., Diop, S., Diaw, M., Brudey, K., Bogui, P., Cissé, F., Hardy-Dessources, M., and Connes, P.(2010): Effects of hydration and dehydration on blood rheology in sickle cell trait carriers during exercise. American Journal of Physiology, Heart and Circulatory Physiology. 299: H908-H914.

Tsaras, G., Owusu-Ansah, A., Boateng, F.O., and Amoateng-Adjepong Y. (2009): Complications Associated with Sickle Cell Trait: A Brief Narrative Review. The American Journal of Medicine. 122:507512.

Waltz, X., Hedreville, M., Sinnapah, S., Lamarre, Y., Soter, V., Lemonne N, Etienne-Julan, M., Beltan, E., Chalabi, T., Chout, R., Hue, O., Mougenel, D., and Hardy-Dessources, M.D.(2012): Delayed beneficial effect of acute exercise on red blood cell aggregate strength in patients with sickle cell anemia. Clinical Hemorheology and Microcirculation 52(1):15-26.

Waltz, X., Romana, M., Hardy-Dessources, M.D., Lamarre, Y., Divialle-Doumdo, L.,Petras, M., Tarer, V., Hierso, R., Baltyde, K., and Tressieres, B.(2013): Hematological and hemorheological Determinants of the SixMinute Walk Test Performance in Children with Sickle Cell Anemia. PLoS One. 8(10): e77830.

Xu, Z., Zheng, Y., Wang, X., Shehata, N., Wang, C.,Xie S, and Sun, Y.(2016): Stiffening of sickle cell trait red blood cells under simulated strenuous exercise conditions. Microsystems \&Nanoengineering. 2 (16061):1-7 